\title{
Bioindicator Thais carinifera (mollusca, gastropoda): imposex response and consequences along the Pakistan coast during the period from 1993 to 2012
}

\author{
Nuzhat Afsar*, Ghazala Siddiqui, Zarrien Ayub
}

\author{
Center of Excellence in Marine Biology (CEMB), University of Karachi (UOK) \\ (Karachi 75270, Pakistan) \\ *Corresponding author: nuzhatafsar259@hotmail.com
}

\begin{abstract}
Endocrine mediated "imposex" phenomenon was investigated and recorded in the muricoid gastropod species Thais carinifera during the two decades from 1993 to 2012 at three (3) sites out of six (6) localities investigated along the Sindh and Balochistan coast, Pakistan. The VDS stages 1 to 4 were apparent in Thais carinifera. The intensity of imposex has remained comparatively low in the populations of harbours in close proximity to port Mohammad Bin-Qasim, namely; Old Korangi Fish Harbour $(\mathrm{OKFH})$ and New Korangi Fish Harbour (NKFH) where shipping activities are sporadic as compared to those in Manora Channel and the adjoining Karachi Port area where intensive shipping activity is rather frequent. Target species found to be good bioindicators have shown a marked decrease over the prolonged study period. Investigations show that this decrease is solely due to globally imposed effective bans on tributyltin (TBT) based antifouling paints over the past decade.
\end{abstract}

Descriptors: Imposex, Gastropod, Biomonitoring, Endocrine Disruption, Karachi Coast.

\section{Resumo}

O fenômeno hormonal "imposex" foi investigado e relatado para o gastrópode muricídeo Thais carinifera durante duas décadas, de 1993 a 2012, em três das seis localidades investigadas ao longo da costa de Sindh and Balochistão, Paquistão. Os estágios VDS 1 a 4 foram aparentes na espécie. A intensidade do imposex permaneceu comparativamente baixa nas populações dos portos próximos do porto de Mohammad Bin-Qasim, especificamente em Old Korangi Fish Harbour (OKFH) e New Korangi Fish Harbour (NKFH), onde as atividades portuárias são esporádicas quando comparadas às de Manora Channel e à área adjacente do Porto de Karachi, onde a atividade portuária é mais intensa. A espécie alvo mostrou-se um bom bioindicador por ter apresentado decréscimo acentuado ao longo do extenso período de estudo. As investigações mostraram que esse decréscimo é apenas devido ao efetivo banimento globalmente imposto da tributiltina (TBT) como base de tintas anti-incrustantes ocorrido na década passada.

Descritores: Imposex, Gastrópodes, Biomonitoramento, Perturbações Endócrinas, Costa de Karachi. 


\section{INTRODUCTION}

The phenomenon of imposex (imposition of male sex characters in females) is directly related to organotin contamination (OTC) in the marine environment due to superfluous organotin compounds in the antifouling paints which were used to protect ships' hulls for decades (AFSAR et al., 2012a, b.; AFSAR et al., 2013). The use of the organotin compounds (OTC) tributyltin (TBT) and triphenyltin (TPT) in antifouling paints was begun in the 1960 s but due to their deleterious effects on marine biota their use was banned during the 1980s and 1990s in many countries of Europe, the USA, Canada, Australia, Canada, New Zealand, Japan and Hong Kong (STEWART, 1996; EVANS et al., 1996, HOURIGUCHI et al., 1994; KO et al., 1995). Legislation was implemented to restrict the use of TBT in antifouling paints (HORIGUCHI et al., 1994; REITSEMA and SPICKETT, 1999).

Despite the ban many countries have experienced decades of the unrestricted use of TBT. To overcome this problem a global ban was imposed on the use of TBT from 2003 onwards, which included the removal of all existing coatings of paints containing TBT by 2008. This was agreed by the International Maritime Organization (IMO) (TRONBJERG, 2001). However, imposex is still evident certainly in and around shipping hubs situated in the North and South American continent (LI and COLLINS 2009; TITLEY-O'NEAL et al., 2011; BORGES et al., 2013; CASTRO et al., 2014) and in European (BRAY et al., 2012) and Asiatic countries (STEPHEN et al., 2003; AFSAR et al., 2012a, b; AFSAR et al., 2013). Recently, AYARI et al. (2014) have quantified imposex in Stramonita haemastoma from the Bizerta Channel, Tunisia - an area with high levels of shipping, exceeding 1000 boats per year, including fishing boats, oil tankers, gas tankers, passenger ships, container ships and naval vessels, and efforts have been made to understand the effect on gastropod size of shell fouling by epibiotic barnacles. Imposex incidence in the Bizerta Channel was found to be higher in females fouled by epibiotic barnacles in contrast to non-fouled females. Likewise COSTA et al. (2014) have also reported penis malformations in Leucozonia nassa and Leucozonia ocellata species from a TBT contaminated region of southeastern Brazil and results showed high levels of TBT contamination in samples collected in Espirito Santo Bay, subjected to intense maritime traffic.

In prosobranch gastropods, the deleterious effect of organotin contamination (OTC) was first observed by BLABER (1970) in the muricid gastropod, Nucella lapillus and the term imposex was first used by SMITH (1971) in relation to the stenoglosson gastropod Nassarius obsoletus (American mud snail). TBT is an endocrine disruptor and its ingestion results in masculinization in gastropods, it is, therefore, suggested that molluscs and particularly snails are the most sensitive organisms in terms of the effects of endocrine disruptors (EDCs) because EDCs directly or indirectly influence their hormonal system at very low concentrations of about 0.5-1 ng/l, (MATTHIESSEN and GIBBS, 1998; DUFT et al., 2007). To date, the organotin contamination in the marine environment, the uptake of OTC's and the resultant imposex dilemma due to endocrine disruption has been observed and explained in more than 260 species of gastropods worldwide, except in the Antarctic region (TITLEY-O'NEAL et al., 2011).

Imposex in gastropods is the most responsive assay for the assessment of TBT and TPT contamination in the natural marine environment. Generally molluscan species belonging to the family Muricoidae such as Nucella lapillus (GIBBS et al., 1987; OEHLMANN et al., 1991), Ocenebra erinacea (GIBBS et al., 1990; OEHLMANN et al., 1992), Morula granulata (REITSEMA and SPICKETT, 1999; AFSAR et al., 2012a, b); Thais clavigera, Thais bronni (HOUIRIGUCHI et al., 1994) and Thais orbita (GIBSON and WILSON, 2003) have served as bioindicators of TBT contamination. The effects of TBT have been documented in many South Asian countries including Singapore, Malaysia, Indonesia and Thailand in many species of muricid gastropods, Thais luteostoma, T. bitubercularis, T. clavigera, T. rufotincta, T. distinguenda, Thais gradate and T. jubilaea, Morula musiva, Cronia margariticola, Drupella rugosa, Morula musiva, M. granulata, M. margariticola, Chicoreus capucinus and Naquetia capucina (ELLIS and PATTISINA, 1990; TAN, 1997, 1999; HUNG et al., 2001, BECH, 2002a, b). This phenomenon has also been recorded and documented in India and Pakistan in a number of species such as T. bufo, T. rudolphi, T. tissoti, Cronia konkanesis and Gryineum natator (VISHWAKIRAN and ANIL, 1999; TEWARIA et al., 2002,; VISHWAKIRAN et al., 2006; AFSAR et al., $2012 \mathrm{a}, \mathrm{b}$; AFSAR and SIDDIQUI, 2013).

Molluscan Thais species belonging to the family Muricoidae are widely distributed along the Pakistan coast and are also highly sensitive to organotin pollution. This present study also provides an insight into the occurrence of imposex in muricoid Thais carinifera, and its spatial and temporal progression and also reflects the subsequent decrease due to imposed global bans on TBT-based antifouling paints in recent decades. 


\section{MATERIAL AND METHODS}

\section{Study Area And SAmpling}

Samples of Thais carinifera were obtained from six (6) sites located on the Sindh and Balochistan coasts (Figure 1) during six surveys between 1993 and 2007 and finally in December 2012, according to their availability and population size. Sampling was undertaken at different intervals during the surveys: from August to December 1993 and January to July 1994 (survey 1); November to December 1998 and January to June 1999 (survey 2); April to December 2003 and January to July 2004 (survey 3); February to December 2005 and January to July 2006 (survey 4); July 2007 (survey 5) and December 2012 (survey 6).

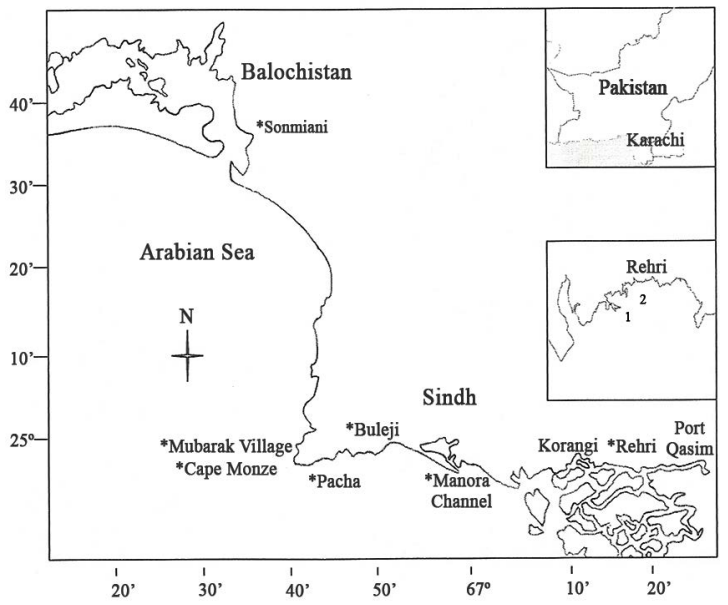

Figure 1. Map showing collection sites*. 1: New Korangi Fish Harbour (NKFH); 2: old Korangi Fish Harbour (OKFH).

Three sampling sites (Figure 1): Manora Channel (24 $48^{\prime} \mathrm{N} ; 66^{\circ} 58^{\prime} \mathrm{E}$ ) adjoining the largest Karachi shipping port, Old Korangi Fish Harbour (OKFH) $\left(24^{\circ} 48^{\prime} \mathrm{N} ; 66^{\circ}\right.$ $\left.58^{\prime} \mathrm{E}\right)$ and New Korangi Fish Harbour (OKFH) $\left(24^{\circ} 48^{\prime}\right.$ $\left.\mathrm{N} ; 66^{\circ} 14^{\prime} \mathrm{E}\right)$. Areas situated in the vicinity of the second largest shipping port of the country, port Mohammad Bin-Qasim were included in the surveys because of the large scale commercial shipping activity in these areas. Three (3) other sites (Figure 1): Cap Monze ( $24^{\circ} 50^{\prime} \mathrm{N}$; $67^{\circ} 14^{\prime} \mathrm{E}$ ), Mubarak Village ( $24^{\circ} 50^{\prime} \mathrm{N} ; 66^{\circ} 39^{\prime} \mathrm{E}$ ) and Sonmiani $\left(25^{\circ} 25^{\prime} \mathrm{N} ; 66^{\circ} 35^{\prime} \mathrm{E}\right)$ were used to obtain samples for comparative analysis as fishing activities there are restricted and only small fishing trawlers usually operate in these areas. No commercial large scale shipping activity takes place there. Cape Monze is a clean site and no shipping activity occurs in the nearby area.

\section{MeAsurements AND IMPOSEX DETECTION}

The specimens were brought live to the laboratory and frozen until further analysis. The animals were thawed prior to examination, then biometric and morphometric investigations were carried out. Animal sex identification, measurements of frequency and intensity of imposex, vas deferens sequence stages (VDS) and vas deferens sequence index (VDSI) were made as already detailed (AFSAR et al., 2012a, b).

The vas deferens sequence stages (VDS) and vas deferens sequence index (VDSI) were determined only in the samples procured as from 2003. The VDSI was calculated as the average of the imposex stages described by OEHLMANN et al. (1996). Stages of imposex and imposex development for muricoid Thais carinifera were outlined in the light of the general imposex scheme described by STROBEN et al. (1992), OEHLMANN et al. (1992) and then by VISHWAKIRAN and ANIL, (1999) as shown in the schematic diagram (Figure 2). The imposex stages of Thais carinifera (Figure 2) are based on the characteristics given below:

Stage 0 : Morphologically normal females without any characteristic male features (without penis or VDS). Stage 1: Characterized by the presence of a small penis without a penile duct behind the right ocular tentacle in imposex females. Stage 2: Penis with a closed penile duct behind the right ocular tentacle. Stage 3: Penis with penile duct which continues in a short distal portion of the vas deferens. Stage 4: Penis with a penile duct and a vas deferens that runs continuously from the base of the penis up to the vulva (vaginal opening).

\section{STATISTICAL DATA ANALYSIS}

The mean difference in male/female shell length and the mean difference in male and imposex female penis length of the pooled data was tested by multiple range tests used in ANOVA between groups and within groups, to analyze the relationship between penis length and shell length in different spans (in different periods?) over the study period. When the $P$-value of the F-test in ANOVA is greater than or equal to 0.10 , there is no statistically significant relationship between penis length and shell length. Male and imposex female shell length and penis length correlation was also tested statistically by using the $t$-test. A nonparametric Kruskal Walis test was used to analyze the variation in average penis length of males and imposex females within groups and between surveys (1-5) to 

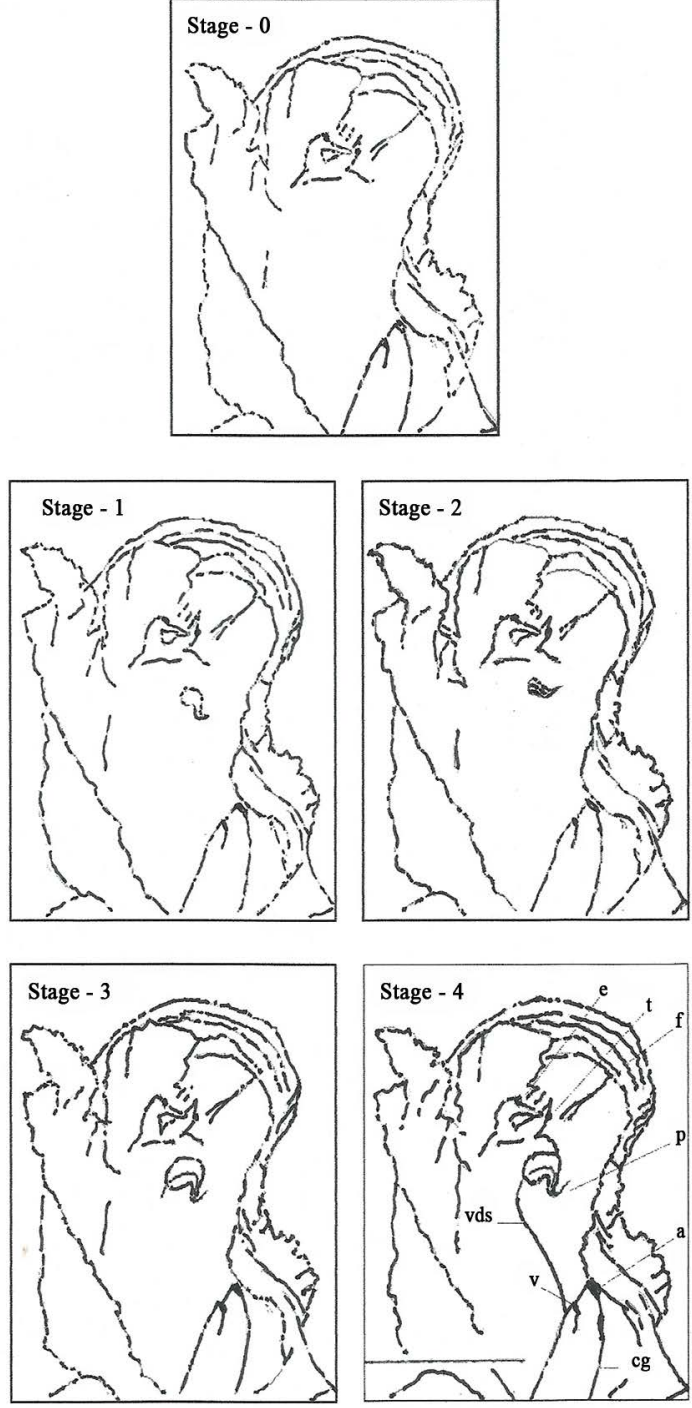

Figure 2. Imposex stages (1-4) recorded in Thais carinifera. a: anus; cg: capsule gland; e: eye; f: foot; p: penis; t: tentacle; vds: vas deferens sequence; v: vulva. Scale bar: $30 \mathrm{~mm}$.

determine whether the average penis length of males and females was increasing in relation to the surveys undertaken in different years. To test whether the high incidence of imposex has affected the populations and to see if the sex ratio has turned into a male dominated population, a chi-square test was performed to compare sex ratios (BECH, 2002a, b). Statistical data analyses were performed using Statgraphics plus (5.1).

\section{RESULTS}

The imposex females were only present in the Manora Channel, new Korangi Fish Harbour (NKFH) and old
Korangi Fish Harbour (OKFH). In the Manora Channel during the first survey the incidence of imposex was $59.32 \%$ which increased to $73.84 \%$ in the third survey. However, in the fifth survey a considerable decline in the incidence of imposex (27.27\%) was recorded. Further, in the last, the sixth, survey there was no sign of imposex found in any specimen of $T$. caranifera (Table 1). The RPSI of this species in the Manora Channel was 13.02 in the first survey which diminished to 0.14 in the fifth survey. The RPLI also decreased from 50.69 in the first survey to 11.11 in the last survey. The VDSI increased from 0.15 in the third survey to 0.89 in the fifth survey (Figure 3).

A significant decrease in female shell length (ANOVA, $\mathrm{F}=20.76 ; p<0.001)$ was observed in specimens examined from the Channel, and the average shell length decreased from $52.30 \pm 8.22 \mathrm{~mm}$ in the first survey to $46.58 \pm 6.69$ $\mathrm{mm}$ in the fifth survey). In males also, a significant variation in shell length was noted in specimens examined during the first five surveys (ANOVA, $\mathrm{F}=10.67 ; p<0.001$ ). The sex-ratio was close to a 1:1 theoretical ratio in all the surveys except for the fifth in which the sex-ratio was in favor of females $\left(\mathrm{x}^{2}=5.12 ; p<0.05\right)$. (Tables 1,2$)$.

The VDS stages were only examined in the third, fourth and fifth surveys. In these surveys the VDS stages 1-4 were found in T. carinifera. Table 1 and Figure 3 show RPLI, RPSI and penis length of imposex females at different VDS stages calculated from the overall pooled data of surveys 3 to 6 (Figure 3). An increase in penis length was observed with respect to an increase in VDS stages, which increased from $2.03 \pm 1.38$ in 1a to $3.85 \pm 2.12$ in stage 4 . The RPLI also increased from $14.57 \%$ in stage 1 to $27.64 \%$ in stage 4 , consequently RPSI was also increased from 0.31 to 2.11 . In the Korangi Creek area the samples were only examined in the third survey from NKFH and OKFH. At NKFH the incidence of imposex was higher (43.18\%) than at OKFH $(12.12 \%)$. The RPLI, RPSI and VDS values are given in Table 1 . They were slightly higher at NKFH. The females were significantly more numerous than males at NKFH $\left(\mathrm{x}^{2}=9.92 ; p<0.05\right)$ and OKFH $\left(\mathrm{x}^{2}=5.12 ; p<0.05\right)$. The imposex females with VDS stages 1, 2 and 4 were present at NKFH, whereas only females with stages 1 and 2 were found at OKFH.

There was no significant correlation between female shell length and penis length (Figure 4) for the overall pooled data from Manora Channel $(\mathrm{r}=0.050 ; p<0.001)$. Similarly no significant correlation between male shell length and penis length was observed. However, a 
Table 1. Imposex incidence (\%) sex-ratios and chi-squared distribution of neogastropod species Thais carinifera at different sites during surveys (1-6). n-sample size; NKFH - new Korangi Fish Harbor; OKFH - old Korangi Fish Harbour.

\begin{tabular}{llcccccc}
\hline Survey & Site & $\mathbf{n}$ & $\begin{array}{c}\text { Proportion } \\
\text { of males }\end{array}$ & $\begin{array}{c}\text { Incidence of } \\
\text { IS (\%) }\end{array}$ & RPLI & RPSI & VDSI \\
\hline 1 (1993-1994) & Manora Channel & 103 & 0.43 & 59.32 & 50.69 & 13.02 & - \\
$2(1998-1999)$ & $"$ & 183 & 0.48 & 70.83 & 39.34 & 6.09 & - \\
& Sonmiani & 100 & 0.48 & - & - & - & - \\
& Cap Monze & 7 & 0.71 & - & - & - & - \\
$3(2003-2004)$ & Manora Channel & 291 & 0.41 & 43.18 & 15.55 & 0.38 & 0.16 \\
& NKFH & 63 & 0.30 & 12.12 & 7.83 & 0.05 & 0.09 \\
& OKFH & 50 & 0.34 & 73.84 & 18.51 & 0.63 & 0.15 \\
& Mubarak Village & 30 & 0.20 & - & - & - & - \\
$4(2005-2006)$ & Manora Channel & 38 & 0.55 & 70.59 & 24.79 & 1.52 & 0.83 \\
& Sonmiani & 38 & 0.42 & - & - & - & - \\
$5(2007)$ & Manora Channel & 50 & 0.34 & 27.27 & 11.11 & 0.14 & 0.89 \\
& Sonmiani & 60 & 0.43 & - & - & - & - \\
\hline \multirow{2}{*}{$(2012)$} & Manora Channel & 47 & 0.44 & - & - & - & - \\
\hline
\end{tabular}
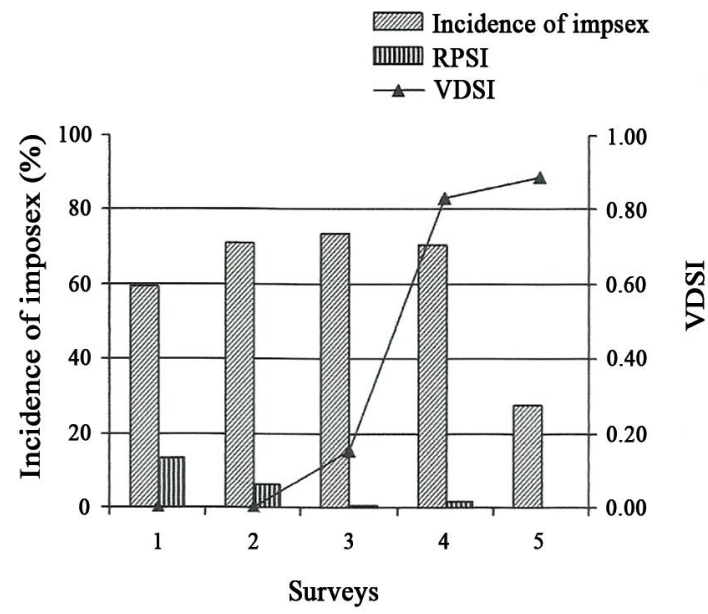

Figure 3. Imposex indices of Thais carinifera from Manora Channel during surveys (1-5) showing temporal trends. IS: imposex; RPSI: relative penis size index; VDSI: vas deferens sequence index.

significant difference between the male and female average penis length in this species was evident (ANOVA, $F=1110.91 ; p<0.001)$. The average length of the female penis (Kruskall Wallis test) increased significantly $(p<0.001)$ from the first survey to the fifth (2007). At the remaining four sites no incidence of imposex was found in $T$. carinifera. At Sonmiani the sex-ratio was close to the theoretical 1:1 ratio in all the surveys. However, at Mubarak Village females were significantly more numerous in this species $\left(\mathrm{x}^{2}=10.80 ; p<0.05\right)$.

\section{DISCUSSION}

Though surveys were carried out at six sites along the Sindh and Balochistan coasts during the period from 1993 to 2012, the imposex which is the masculization of female gastropods was detected in Thais carinifera in the Manora Channel, OKFH and NKFH, the areas adjacent to ports and harbours experiencing shipping activity. The presence of imposex females at these sites indicated the localized effect of organotin contamination in Pakistan. The severity of imposex was more pronounced in the Manora Channel which is the shipping line leading to Karachi Port, the largest port in the country. Besides that, the Lyari River also discharges its domestic and industrial effluents into the Channel and the flushing in the Channel is poor (AFSAR et al., $2012 \mathrm{a}, \mathrm{b})$. The other two contaminated sites, NKFH and $\mathrm{OKFH}$, are located on the route of a smaller deep-sea port (Port Mohammed Bin Qasim), the occurrence of imposex in the population of gastropods in these areas suggests that passing vessels are the main source of TBT contamination. In Pakistan, there are no aquaculture facilities or other structures coated with antifouling paints and thus ship related activities must be the major source of TBT contamination in coastal waters. Besides, the neighboring Gulf of Oman is also an integral part of the North Arabian Sea, and counter part of shipping routes in the region has fairly intense shipping including 
Table 2. Biometric data of Thais carinifera calculated during surveys (1-6) NKFH: new Korangi Fish Harbour; OKFH: old Korangi Fish Harbour; SD: standard deviation.

\begin{tabular}{|c|c|c|c|c|c|c|c|}
\hline Survey & Site & $\begin{array}{l}\text { Manora } \\
\text { Channel }\end{array}$ & NKFH & OKFH & $\begin{array}{c}\text { Cape } \\
\text { Monze }\end{array}$ & $\begin{array}{c}\text { Mubarak } \\
\text { Village }\end{array}$ & Sonmiani \\
\hline \multirow[t]{6}{*}{ Male shell length $\pm \mathrm{SD}(\mathrm{mm})$} & 1 & $49.84 \pm 6.73$ & - & - & - & - & - \\
\hline & 2 & $51.68 \pm 5.48$ & - & - & $43.6 \pm 2.190$ & - & $42.54 \pm 7.22$ \\
\hline & 3 & $47.80 \pm 5.33$ & $36.50 \pm 8.77$ & $36.52 \pm 4.25$ & - & $45.16 \pm 5.56$ & $47.38 \pm 6.39$ \\
\hline & 4 & $44.42 \pm 3.58$ & - & - & - & - & $35.56 \pm 7.64$ \\
\hline & 5 & $50.76 \pm 5.09$ & - & - & - & - & $49.19 \pm 8.21$ \\
\hline & 6 & $48.38 \pm 4.31$ & - & - & - & - & - \\
\hline \multirow[t]{5}{*}{ Female shell length $\pm \mathrm{SD}(\mathrm{mm})$} & 1 & $52.30 \pm 8.22$ & - & - & - & - & - \\
\hline & 2 & $52.27 \pm 6.37$ & - & - & $45 \pm 2.82$ & - & $43.71 \pm 7.41$ \\
\hline & 3 & $47.82 \pm 6.02$ & $45.68 \pm 12.22$ & $37.68 \pm 5.75$ & - & $45.20 \pm 2.96$ & $45.64 \pm 6.43$ \\
\hline & 5 & $46.58 \pm 6.69$ & - & - & - & - & $47.38 \pm 9.70$ \\
\hline & 6 & $48.73 \pm 3.21$ & - & - & - & - & - \\
\hline \multirow[t]{6}{*}{ Male penis length $\pm \mathrm{SD}(\mathrm{mm})$} & 1 & $8.10 \pm 2.72$ & - & - & - & - & - \\
\hline & 2 & $11.61 \pm 1.94$ & - & - & $11.2 \pm 2.167$ & - & $11.10 \pm 2.81$ \\
\hline & 3 & $14.53 \pm 3.55$ & $11.00 \pm 4.03$ & $9.64 \pm 2.42$ & - & $\begin{array}{c}15.33 \pm \\
1.861\end{array}$ & $17.31 \pm 3.21$ \\
\hline & 4 & $11.09 \pm 2.84$ & - & - & - & & $9.12 \pm 3.11$ \\
\hline & 5 & $13.05 \pm 1.51$ & - & - & - & - & $12.50 \pm 2.02$ \\
\hline & 6 & $15.71 \pm 1.61$ & & - & - & - & - \\
\hline \multirow[t]{5}{*}{ Female penis length $\pm \mathrm{SD}(\mathrm{mm})$} & 1 & $4.06 \pm 2.47$ & - & - & - & - & - \\
\hline & 3 & $2.77 \pm 1.55$ & $0.94 \pm 1.20$ & $1.25 \pm 0.50$ & - & $0.00 \pm 0.00$ & $0.00 \pm 0.00$ \\
\hline & 4 & $2.83 \pm 1.33$ & - & - & - & - & $0.00 \pm 0.00$ \\
\hline & 5 & $1.68 \pm 1.84$ & - & - & - & - & $0.00 \pm 0.00$ \\
\hline & 6 & $0.00 \pm 0.00$ & - & - & - & - & - \\
\hline
\end{tabular}

a large number of transiting oil tankers (STEPHEN et al., 2003). During the survey of organotin compounds, notable concentrations of organotin contamination were measured in marine sediments and biota from the Gulf, in the coastal zone of Bahrain, Qatar and the United Arab Emirates, and the adjacent region (STEPHEN et al., 2003).

Many species of Thais, namely, T. clavigera, T. jubilaea and $T$. bitubercularis were found to be affected by imposex on the coast of mainland Singapore due to the large number of vessels calling at the port of Singapore (TAN, 1997, 1999). Similarly T. clavigera, T. jubilaea, T. gradata and T. bitubercularis living in the vicinity of harbours, marinas and ports have been known to develop imposex in Singapore and Indonesian coastal waters (ELLIS and PATTISINA, 1990; TAN, 1999). The studies conducted along the central and west coast of India also confirm the localized effect of TBT contamination at sites with ship-related activities (VISHWAKIRAN and ANIL, 1999; VISHWAKIRAN et al., 2006). Similarly from Australia, WILSON (1993) and GIBSON and WILSON (2003) have provided evidence that TBT is the main chemical responsible for the development of imposex in T. orbita with significantly higher frequencies in harbours than on the open coastline.

Fairly large numbers of specimens of $T$. carinife$r a$ were found in all the surveys and the intensity of imposex ranged between $46.03 \%$ and $73.84 \%$ except in the last survey (2007) when it declined to $27.27 \%$ and finally to $0 \%$ in 2012 . The incidence of imposex in T. carinifera in the Manora Channel increased significantly from 1993-1994 to 2005-2006 (Surveys 1-4); however, in the last surveys (2007 and 2012) a 


\section{(IS)}

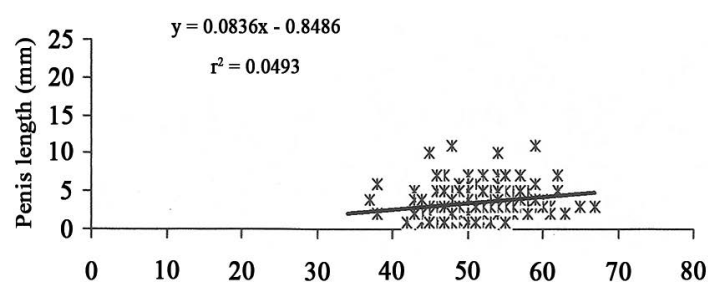

(M)

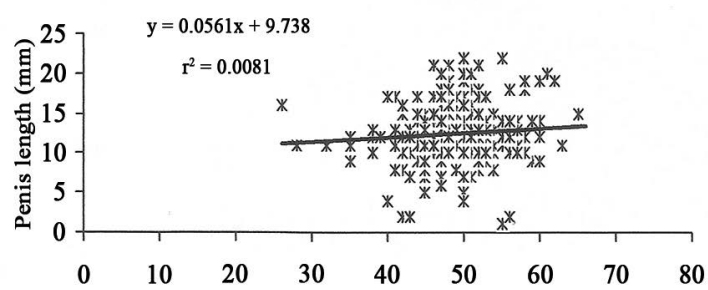

Figure 4. Thais carinifera: Correlation between shell length and penis length of males (M) and imposex (IS) based on pooled data from Manora Channel.

considerable decline in the incidence of imposex was observed. This could have been due to the reinforcement of the global ban on the use of TBT - based paints worldwide. The Manora Channel is a route for international shipping to the Karachi Port, the largest in the country, and foreign vessels seem to be the only source of TBT contamination in the area. The reinforcement, in 2003, of the global ban on the use of new applications of TBT-based paints and legislation on the removal of existing organotin coatings on ships and vessels by 2008 , by the International Maritime Organization (IMO) has helped to reduce the incidence of imposex in many species of gastropods throughout the world. A considerable decline in the incidence of imposex after the implementation of the ban on the use of TBT-based paints has been reported in Nucella lapillus from the UK (EVANS et al.,1996), in Lepsiella scuba from New Zealand and in T. orbita from Australia (GIBSON and WILSON, 2003). Despite that fact, concentrations of organotin (OTC) contamination are still evident as a result of unrestricted shipping-related activities in a number of countries. Despite the global ban, increasing imposex levels have been detected in Stramonita haemastoma analyzed in 2004 and 2011, in southeastern Brazil (BORGES et al., 2013). Similarly butyltin species have been recorded in sediments from coastal locations in the Gulf and in the Gulf of Oman in biota samples from four countries in the region. Levels of organotin species have been found to be comparatively low in accordance with global standards - which assert no direct public health problems. (STEPHEN et al., 2003).

The imposex indices such as RPLI, RPSI and VDSI are considered to be useful tools for the assessment of imposex intensity (VISHWAKIRAN et al., 2006). In the imposex specimens examined during the present study, early and intermediate stages (stages up to 4) of imposex were detected, consequently lower RPLI, RPSI and VDSI values were recorded compared to elsewhere in the world, where higher imposex indices were reported in the affected population of many species of gastropods (BRYAN et al., 1987; GIBBS et al., 1988; STROBEN et al., 1992). OLIVEIRA et al. (2011) assessed imposex levels in Nucella lapillus (dog whelk) along the Portuguese coast in 2006 and 2008 and a significant decline in imposex intensity was recorded, confirming the effectiveness of the Regulation (EC) $N^{\circ} 782 / 2003$ in reducing TBT pollution.

During the present study in general an increase in female penis length was observed with respect to the increase in the VDS stages in specimens of $T$. carinifera. However, in some individuals a decrease in penis length was also recorded with an increase in VDS stage. This variability in the length of female penis related to an increase in VDS stages or to increased levels of imposex has been reported in Hinia reticulata (STROBEN et al., 1992). They attributed this variability to a random cause rather than seasonal variation, as was found in males whose penis size increases during the spawning season.

Variation in RPSI and VDSI over time was also studied in this species. Considerable variation in RPSI values were observed in different surveys, although there was a steady increase in the value of VDSI from the third (2003-2004) to the fifth survey (2007). The VDSI is considered to be a better index than RPLI and RPSI because in gastropod species, the male penis length varies in relation to the spawning seasons (TAN, 1997; HUNG et al., 2001; BECH, 2002b). Therefore, VDSI is preferred by many researchers for the assessment of imposex (OEHLMANN et al., 1991; STROBEN et al., 1996; VISHWAKIRAN et al., 2006). 
In the present study no correlation was found between female shell length and penis length for the overall pooled data of $T$. carinifera $(\mathrm{r}=0.050 ; p<$ 0.01 ). Similarly, no significant correlation between male shell length and penis length in this species was observed. Likewise, BECH (2002b) in T. distinguen$d a$ from Thailand observed no significant correlation between female penis length and shell length; however, he did find a significant correlation between male penis length and shell length. On the other hand, HUNG et al. (2001) recorded a significant positive relationship between female penis length and shell size in samples of $T$. clavigera from Taiwan. Similarly in $T$. gradata and Neptunea antique from Singapore (TAN, 1999; POWER and KEEGAN, 2001) a significant correlation was reported in male shell length and penis length, whereas there was no significant correlation between female shell length and penis length. In $T$. carinifera a significant difference in male and female penis length was observed, differently from the condition observed in species of Nucella in which generally very small variation in male and female penis length was found (BRIGHT and ELLIS, 1990). TAN (1999) suggested that each species has its own penis/pseudopenis characteristics.

In the present study the last VDS stage exhibited by the imposex females was 4 , which is the last fertile stage of imposex in muricid gastropods; there is, therefore, no chance of infertility in the gastropod species examined. In the VDS stage 4 , the penis has a penis duct and a vas deferens which continues from the penis up to the vulva and all the functioning glands in the pallial oviduct are assisted by a normal pedal gland which allows the deposition of normal egg capsules. Nor, further, is the vaginal opening modified or the capability of copulation conserved (?). However, in females with advanced stages (5-7), the absence and occlusion of the vulva leads to reproductive failure (GIBBS and BRYAN, 1988; OEHLMANN et al., 1996; STROBEN et al., 1992).

The present study of the morphological evidence in Thais carinifera reveals the occurrence of organotin contamination in Pakistani waters. The development of imposex in affected species has not reached the point at which it can disturb the reproductive cycle, however, to elucidate the impact of imposex on the population dynamics of these species, the life cycle and the recruitment pattern of marine gastropod species need to be further examined for the future management and control of OTCs in Pakistani coastal waters specially at Gadani ship-breaking yards, the world's third largest ship dismantling industrial zone, along the Balochistan coast, Pakistan where the imposex phenomenon is still evident in native neogastropods (unpublished data).

\section{ACKNOWLEDGEMENTS}

This study was supported under the Research Project, Pakistan Science Foundation (PSF) and through a grant from the Center of Excellence for Marine Biology (CEMB), University of Karachi. The authors are grateful to all those involved in the project and for the financial assistance provided.

\section{REFERENCES}

AFSAR, N.; SIDDIQUI, G.; AYUB, Z. Record of imposex in Morula granulate (Mollusca: Gastropoda: Muricidae) from Pakistan. Pak. J. Zool., v. 44, n. 2, p. 572-576, 2012 a.

AFSAR, N.; SIDDIQUI, G. Report of imposex syndrome in Thais tissoti (Neogastropoda) from vicinity of Karachi port, Pakistan. Pak. J. Zool., v. 45, n. 5, p. 1475-1478, 2013.

AFSAR, N.; SIDDIQUI, G.; AYUB, Z. Imposex detection in Babylonia spirata (Gastropoda: Buccinidae) from Pakistan (Northern Arabian Sea). Indian J. Geo-Mar. Sci., v. 41, n. 5, p. 418-424, 2012b.

AYARI, T.; ABIDLI, S.; LAHBIB, Y.; GONZÁLEZ, P. R.; ALONSO, J. G.; TRIGUI-EL MENIF, N. The effect of size and epibiotic barnacles on imposex in Stramonita haemastoma collected from the northern coast of Tunisia. Mar. Biol. Res., v. 11, n. 3, p. 313-320, 2014.

$\mathrm{BECH}, \mathrm{M}$. Imposex and tributyltin contamination as a consequence of the establishment of a marina and increasing yachting activities at Phuket Island, Thailand. Environ. Poll., v.117, n. 3, p. 421-429, 2002a.

BECH, M. A survey of imposex in muricids from 1996 to 2000 and identification of optimal indicators of tributyltin contamination along the east coast of Phuket Island, Thailand. Mar. Pollut. Bull., v. 44, n. 9, p.887-896, 2002b.

BLABER, S. J. M. The occurrence of a penis-like outgrowth behind the right tentacle in spent females of Nucella lapillus (L.). Proc. Malacol. Soc. London., v. 39, p. 231-233, 1970.

BORGES, C. L. L.; FERNANDEZ, M. A. S. F.; CASTRO, I. B.; FILLMANN, G. Organotin pollution from pleasure craft at Paraty, a tourist area of southern Brazil: amelioration or interference? Braz. J. Oceanogr., v. 61, n. 3, p. 177-186, 2013.

BRAY, S.; MCVEAN, E. C.; NELSON, A.; HERBERT, R. J. H.; HAWKINS, S. J.; HUDSON, M. D. The regional recovery of Nucella lapillus populations from marine pollution, facilitated by man-made structures. J. Mar. Biol. Ass. U. K., v. 92, n. 7, p. 1585-1594, 2012. 
BRIGHT, D. A.; ELLIS, D. V. Comparative survey of imposex in Northeast Pacific neogastropods (Prosobranchia) related to tributyltin contamination, and choice of a suitable bioindicator. Canadian J. Zool., v. 68, n. 9, p. 19151924, 1990.

BRYAN, G. W.; GIBBS, P. E.; BURT, G, R.; HUMMERSTONE, L. G. The effects of tributyltin (TBT) contamination on adult dog-whelks, Nucella lapillus: long term field and laboratory experiments. J. Mar. Biol. Ass. U. K., v. 67 , n. 3, p. 525-544, 1987.

COSTA, M. B.; MARDEGAN, B. S.; ZAMPROGNO, G. C.; PEDRUZZI, F. C.; MORAIS, L. D.; DALBEM, G. B.; SILVA, D. A.; GRACELI, J. B. Penis Malformations in Leucozonia nassa (Gmelin, 1792) and Leucozonia ocellata (Gmelin, 1791) in a TBT Contaminated Region from Brazil. Aquatic. Sci. Technol., v. 2, n. 2, p. 52-66, 2014.

DUFT, M.; SCHMITT, C.; BACHMANN, J.; CORNELIUS, BRANDELIK, C.; OEHLMANN, S.; OEHLMANN, J. Prosobranch snails as test organisms for the assessment of endocrine active chemicals--an overview and a guideline proposal for a reproduction test with the freshwater mudsnail Potamopyrgus antipodarum. Ecotoxicology, v. 16, n. 1, p. 169-182, 2007.

ELLIS, D. V.; PATTISINA, L. A. Widespread neogastropod imposex: A biological indicator of global TBT contamination? Mar. Pollut. Bull., v. 21, n. 5, p. 284-253, 1990.

EVANS, S. M.; EVANS, P. M.; LEKSONO, T. Widespread recovery of dogwhelks, Nucella lapillus (L.), from tributyltin contamination in the North Sea and Clyde Sea. Mar. Pollut. Bull., v. 32, n. 3, p. 263-269, 1996.

GIBBS, P. E.; BRYAN, G. W.; PASCOE, P. L.; BURT, G. R. Reproductive abnormalities in female Ocenebra erinacea (Gastropoda) resulting from tributyltin-induced imposex. J. Mar. Biol. Ass. U. K., v. 70, n. 3, p.639-656, 1990.

GIBBS, P. E.; PASCOE, P. L.; BURT, G. R. Sex change in the female dogwhelk Nucella lapillus induced by tributyltin from antifouling paints. J. Mar. Biol. Ass. U. K., v. 68, n. 4, p.715-732, 1988.

GIBBS, P. E.; BRYAN, G. W.; PASCOE, P. L.; BURT, G. R. The use of the dogwhelk (Nucella lapillus) as an indicator of TBT contamination. J. Mar. Biol. Ass. U. K., v. 67, n. 3, p. 507-524, 1987.

GIBSON, C. P.; WILSON, S. P. Imposex still evident in eastern Australia 10 years after tributyltin restrictions. Mar. Environ. Res., v. 55, n. 2, p. 101-112, 2003.

HORIGUCHI, T.; SHIRAISHI, H.; SHIMUZU, M.; MORITA, M. Imposex and organotin compounds in Thais clavigera and T. bronni in Japan. J. Mar. Biol. Ass. U. K., v. 74, n. 3, p.651-669, 1994.

HUNG, T. C.; HSU, W. K.; MENG, P. J.; Chuang, A. Organotins and imposex in the rock shells, Thais clavigera from the Taiwan oyster mariculture area. Environ. Poll., v. 112, n. 2, p. 145-152, 2001.

KO, M. M. C.; BRADELY, G. C.; NELLER, A. H.; BROOM, M. J. Tributyltin contamination of marine sediments of Hong Kong. Mar. Pollut. Bull., v. 31, n. 4-12, p. 249-253, 1995.

LI, C.; COLLIN, R. Imposex in one of the world's busiest shipping zones. Smithson. Contrib. Mar. Sci., p. 189-196, 2009.
MATTHIESSEN, P.; GIBBS, P. E. Critical appraisal of the evidence for tributyltin-mediated endocrine disruption in mollusks. Environ. Toxicol. Chem., v. 17, n. 1, p. 37-43, 1998.

OEHLMANN, J.; FIORONI, P.; STROBEN, E.; MARKET, B. Tributyltin (TBT) effects on Ocinebrina aciculata (Gastropoda: Muricidae): imposex development, sterilization, sex change and population decline. Sci. Total. Environ., v. 188, n. 2-3, p. 205-233, 1996.

OEHLMANN, J.; STROBEN, E.; FIORONI, P. The rough tingle Ocenebrina erinacea (Neogastropoda: Muricidae): An exhibitor of imposex in comparison to Nucella lapillus. Helgol. Meeres., v. 46, n. 3, p. 311-328, 1992.

OEHLMANN, J.; STROBEN, E.; FIORONI, P. The morphological expression of imposex in Nucella lapillus (Linnaeus) (Gastropoda: Muricidae). J. Moll. Stud., v. 57, n. 3, p. 375-390, 1991.

OLIVEIRA, S. G.; OLIVEIRA, I.; FERREIRA, N.; SANTOS, J. A.; PACHECO, M.; BARROSO, C. Nucella lapillus L. imposex levels after legislation prohibiting TBT antifoulants: temporal trends from 2003 to 2008 along the Portuguese coast. J. Environ. Monit., v. 13, n. 2, p. 304312,2011

POWER, A. J.; KEEGAN, B. F. The significance of imposex levels and TBT contamination in the red whelk, Neptuna antiqua (L.) from the offshore Irish Sea. Mar. Pollut. Bull., v. 42, n.9, p.761-772, 2001.

REITSEMA, T. J.; SPICKETT, J. T. Imposex in Morula granulata as bioindicator of tributyltin (TBT) contamination in the Dampier Archipelago, Western Australia. Mar. Pollut. Bull., v. 39, n.1-12, p. 280-284, 1999.

SMITH, B. S. Sexuality in the American mud snail, Nassarius obsoletus. Proc. Malac. Soc. Lond., 39, p. 377-388, 1971.

STEPHEN J.; MORA.; SCOTT W.; ROBERTO F.; TOLOSA, C. I. Assessment of organotin contamination in marine sediments and biota from the Gulf and adjacent region. Mar. Pollut. Bull., v. 46, n.4, p. 401-409, 2003.

STEWART, C. The efficacy of legislation in controlling tributyltin in the marine environment. In: MORA. S. J. (ed.). Tributlytin: case study of an environmental contaminant. Cambridge: Cambridge University Press, 1996. p. 264-297.

STROBEN, E.; OEHLMANN, J.; FIORONI, P. Hinia reticulata and Nucella lapillus. Comparison of two gastropod tributyltin indicators. Mar. Biol., v. 114, n. 2, p. 289-296, 1992.

STROBEN, E.; OEHLMANN, J.; SCHULTE-OEHLMANN, U.; FIORONI, P. Seasonal variations in the genital ducts of normal and imposex affected prosobranchs and its influence on biomonitoring indices. Malacol. Rev., Suppl. 6, p. 173-184, 1996.

TAN, K. S. Imposex in Thais gradata and Chicoreus capacinus (Mollusca: Neogastropoda: Muricidae) from the straights of Johor: a case study using penis length, area and weight as measures of imposex severity. Mar. Pollut. Bull., v. 39, n.1-12, p. 295-303, 1999.

TAN, K. S. Imposex in three species of Thais from Singapore, with additional observations on $T$. clavigera (Kuster) from Japan. Mar. Pollut. Bull., v. 34, n. 7, p. 577-581, 1997. 
TITLEY-O'NEAL, C. P.; MUNKITTRICK, K. R.; MACDONALD, B. A. The effects of organotin on female gastropods. J. Environ. Monit., v. 13, n. 9, p. 2360- 2388, 2011.

TEWARI, A.; RAGHUNATHAN, C.; JOSHI, H. V.; KHAMBHATY, Y. Imposex in rock whelks Thais and Ocenebra species (Mollusca, Neogastropoda: Muricidae) from Gujarat coast Indian. Hydrobiologia, v. 378, n.1-3, p. 199213, 2002

TORNBJERG, J. Globalt forbud mod giftig skibsmaling. Politiken. (Danish Newspaper) Section 1: 3, October 6, 2001
VISHWAKIRAN, Y.; ANIL, A. C. Record of imposex in Cronia konkanensis (Gastropoda: Muricidae) from Indian waters. Mar. Environ. Res., v. 48, n.2, p. 123-130, 1999.

VISHWAKIRAN, Y.; ANIL, A. C.; VENKAT, K.; SAWANT, S. S. Gyrineum natator: a potential indicator of imposex along the Indian coast. Chemosphere, v. 62, n.10, p. 1718-1725. 2006,

WILSON, S. P.; AHSANULLAH, M.; THOMPSON, G. B. Imposex in neogastropods: An indicator of tributyltin contamination in Eastern Australia. Mar. Pollut. Bull., v. 26, n.1, p. 44-48, 1993. 